\title{
Connecting Research And Practice In An Educational Leadership Program
}

\author{
Wanda S. Maulding, University of Southern Mississippi \\ Gary B. Peters, University of Southern Mississippi \\ Kyna L. Shelley, University of Southern Mississippi \\ Ronald A. Styron, Jr., (Email: Ronald styron@usm.edu), University of Southern Mississippi
}

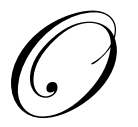

ne of the first acts of President George Bush was to propose legislation that would forever change the face of education in America. That legislation, the No Child Left Behind Act (NCLB) mandated that every child in America make at least marginal progress, deemed 'adequate yearly progress' or AYP each school year (U.S. Department of Education NCLB Executive Summary, 2003). As this legislation filtered down to school systems it meant that data must be collected systematically and routinely at every school at every level to demonstrate the success of all students. This data collection, which has become the foundation for what is now being referred to as 'data-driven decision making,' must become a part of the 'toolbox' of school administrators nationwide. The knowledge of how to collect such data inherently must be at the grasp of K-12 school administrators. It was this driving force, along with what we as former school administrators felt were best practices that led to departmental reform. This reform has now been dubbed the 'Research Thread' for The University of Southern Mississippi's P-12 program of Educational Administration.

\section{THE HISTORY OF EDUCATIONAL LEADERSHIP PROGRAMS}

"By 1900, in a short period of twenty-five years, the university was firmly established in America and was leading the educational parade with its professional character, its utilitarianism and community-centered program" (Berelson, 1960, p. 16). The courses of educational administration were born in the late 1800's (Cooper \& Boyd, 1987)Schools - graduate programs quickly evolved from these early courses. "From 1890 to 1910, courses in administration were transformed into full-blown graduate degree programs in response to the enormous expansion of the public schools" (Levine, p.15, 2005).

These programs, for the most part were divided into two schools of training, one which was highly steeped in theory (Powell, 1976). Late in the century, A Nation at Risk (1983) was published and with it, much scrutiny was placed not only on educational systems in America, but also on their leadership. "The educational foundations of our society are presently being eroded by a rising tide of mediocrity that threatens our very future as a nation and a people" (A Nation at Risk, 1983, p. 5). Specific recommendations from the report dealt with standards and expectations, academic content, time on task, teacher quality, and school leadership.

Following this daunting report, a summit was convened which drafted the 1987 report Leaders for America's Schools. Again, it was reported that America's schools were failing and especially in the area of school leadership. As a matter of fact, the commission recommended closing over half of the nation's schools of leadership.

Finally in 1990, the Levine and Lezotte report Effective Schools was released, identifying the school leader as one of the seven essential elements for effective schools. Yet, despite these recommendations spanning several years, school leader preparation programs have been slow to respond.

\section{THE PARADIGM SHIFT}

In the last decade little has changed with regard to teacher preparation (Goodlad, 1990; Grant, 1994), but there is growing consensus that a restructuring of teacher education programs is warranted (Fullan, 1994; DarlingHammond, 1996; Rigden, 1996). Finney (1992) is critical of colleges and universities for their reluctance to change 
traditional teacher education programs. The model of taking a discrete number of courses, applying for degree and receiving a diploma, although highly criticized, still seems the norm in spite of many mandates for change. However, with the uncompromising belief that school administrators needed to be able to 'do' research, a new model of delivery called "Threaded Research" for educational administration programs was created.

\section{THREADED RESEARCH}

As is frequently recommended in cases where curriculum improvement is needed, program changes were based on an action research model. As a cyclical and collaborative process of change, seeking to "bring together action and reflection, theory and practice" (Stringer, 2004), action research allowed us to examine our own program, reflecting on our own strengths and areas for improvement, and work in conjunction with others to improve our own educational practices in a university setting.

Certainly other Colleges have faced the dilemma of making research more relevant to their students. The future direction of research as it relates to educational practitioners is a reoccurring theme with authors such as Pearson (2003) concluding,

What is the state of educational research now and where is it heading? Right now it seems researchers and practitioners are not on the same page. Their agendas are out of sync and they do not communicate very effectively. While that may sound grim, the future looks more promising. Researchers, practitioners, and policymakers agree that educational research is not as effective as it could and should be and it is time for that to change (p. 2).

The idea of "threaded research" is to seek to balance the delicate scale between theory and practice. By "threading" research instruction and practice throughout the curriculum, research becomes enabling rather than impinging and oppressive, resulting in a more practical outcome for students.

The need to teach research "in context" reflects a growing realization in education programs that students who are, or aspire to be, educational leaders often fail to see the relevance of research coursework to practice. Further, if research courses are viewed as irrelevant then it follows that research itself will often be viewed in the same way. With research courses being taught in isolation - as a stand-alone courses and often as theory-based courses - it is easy to see why this is so. The idea of "threaded research" then is to carefully and deliberately integrate research into the student's coursework - to ensure that research not be separable from content or practice.

The majority of students in educational leadership programs are practitioners in pre-kindergarten through 12th grade settings. These students have traditionally engaged in a single major research project during the course of their academic career - the dissertation. Typically utilizing quantitative analyses and traditional research design, the dissertation process does little to demonstrate or convince students that research can be a valuable tool after they leave the program.

\section{Reflection}

As we began to consider how to create an atmosphere in our program that was reflective of what current school administrators were grappling with, we also acknowledged that there was a huge disconnect for our students between research and statistics and what was going on in their schools. This was the first mission that we had to accomplish, to help students become comfortable with research and to help them identify with how this process connected to data-driven decision making. We wanted students to see the relationship of research in their coursework to the nature of solving problems at their schools.

\section{Planning}

The goals for this curricular change were threefold. First, it was important for our students to have the skills to make those data-driven decisions being mandated by No Child Left Behind legislation. The second goal was to 


\section{Number 3}

allow students to discover the relevance of research to practice. Finally, as perceived relevance increases, appreciation for the potential of research may grow as well. Literature suggests that teachers and educational administrators after conducting their own research projects report that their research experience proved helpful in their job, facilitated hiring, data analysis and evaluation, and curriculum and policy decision-making (Desforges, 2003 ). Therefore, not only might our students begin using research to inform practice, we viewed it likely that the student research culture of the department will undergo a gradual change in which the disconnect between research and practice is slowly resolved.

We decided to begin our program for all students with a basic course in educational statistics and design. Following completion of this course, students would engage in our new two-semester applied research experience directly related to the core content coursework. This year-long research project, an application-based field problem would be developed over the course of the student's study and would consist of directed research in a content area of the student's choosing. The guidance and instruction for the research would come through a specific course number by full-time members of our research faculty in collaboration with the core content faculty.

Both Keller's (ARCS) (1987) and Gagné's (1977) models for motivation and learning provided the basis for designing and implementing this new applied research sequence. Though originally conceived to apply to technology training, Keller proposed that learner motivation must start with attention (A) then, relevance (R). If these conditions are satisfied, confidence (C) and satisfaction (S) should be addressed sequentially in order for learning to occur. Due to recent curricular changes that place more emphasis on and increase the number of our research and statistics classes, it is clear that students are aware of the need to "do" research and statistics during their university program. What is not present, however, is perceived relevance, either during the program or beyond, by the students. Instructional approaches that increase relevance have been shown more successful in enhancing the motivation and learning performance of students than other embedded approaches (Means et al., 1997).

A further complication is the anxiety and fearfulness that are common among students who are facing the prospects of conducting research. As with much course content that is perceived as highly specialized and technical, research and data analysis are activities met with low levels of confidence by students. Without these two essential elements, relevance and confidence, there is little likelihood that students will embrace research as a worthwhile activity. While addressing all four of the parts of Keller's ARCS model, the development of our research thread focused primarily on the critical second and third serially related steps - the conditions that "material" (in this case, research and research activity) must be viewed as relevant and that students have confidence in their research capabilities.

Three overarching principles guided the development of our applied research sequence: Flexibility, Responsibility, and Collaboration.

\section{Flexibility}

\section{Flexibility Of Topic}

Within each student's discipline, they are encouraged to select a research topic that coincides with their professional goals and values and is tied to one or more of their core courses. This is indeed one of the motivating factors for our students - their ability to select an area that is meaningful to them and one for which they need answers. These hybrid research projects combine the driving force of personal interest with appropriate research technique to address an area of interest.

\section{Flexibility Of Research Goals}

Despite the commonalities that unite school leaders, there is nonetheless a wide range goals that research can be used to accomplish. Students are asked to identify, not only their topic of interest but also to identify and articulate 
their research goals. Whereas some may propose the need for evaluation procedures within their school or district, others may seek to solve a problem, and yet others may focus on improving practice.

\section{Flexibility Of Approach}

Another objective for this research sequence is that students learn to adapt the basic concept of inquiry. The course strives to provide an environment cognizant of the broad definition of research and that, within this context, research activity can take numerous forms. Whereas some research may fit the definition of applied research, seeking to solve an identified problem, other research may be action research in which one designs, conducts, and analyzes data to improve one's own practice. Some may choose traditional quantitative research; for others such as educational practitioners it is the immediacy, practicality, and directness of action research that may be of particular interest.

\section{Flexibility Of Methodology}

Because the research projects are highly individual, students will develop, not only the project idea, goals, and approach, they will also identify a methodology (ies) appropriate for the project they have selected.

Multiple Learning Preferences (Rasmussen \& Davidson-Shivers, 1998) (Rasmussen et al., 1998)

As with any skills-based course, much attention is given to students' learning style differences. While much of the course consists of active learning situations through group interaction and projects, other parts of the course are designed for reflective learning.

\section{Personal responsibility}

Having not only selected a research project in their own area of interest, but also a project with potential impact at their own school or district, students develop a strong sense of ownership of the project, an investment that results in greater commitment to its goals, methods, outcomes, and application. This personal responsibility also results in increasing confidence that comes from success in meeting increasingly more difficult challenges in the research process. By 'practicing' research - the application of new knowledge and skills- in a safe and controlled setting such as a classroom, students are more willing to take personal research risks. And, with these incremental successes come further confidence, continued engagement, and a higher likelihood of using the skills learned beyond the classroom.

To extend personal responsibility further and encourage a broader appreciation for the importance of research, students are expected to submit their completed project for appropriate dissemination. They may, for example, submit a manuscript for publication, an abstract for a conference presentation, or present a workshop, training or information session so that their own research findings may benefit others in the field. Presenting their own work for peer review helps demonstrate to the students that the quality of the product or outcome from their research is directly related to the effort they have personally devoted to the project.

\section{Collaboration}

The cohort model for learning organizations has been shown to promote collaboration (Fenning, 2004). This is true for our own Master's program as well although no formal cohort currently exists above the Masters level. The Applied Research sequence creates a research cohort which, despite the individuals' differences in research projects nonetheless brings together a group facing common tasks, learning common skills, and seeking common outcomes. Many of the intermediate assignments take advantage of the importance of collaboration through peer critiques, work groups, and team approaches for specific tasks. Although educational administration students constitute the majority of the course enrollment, other students from other professional education programs are encouraged to participate in the course. The intentional multidisciplinary focus further extends the collaboration that is often critical in research and is a typical part of the school environment. 
After determining the course of change, many objectives had to be accomplished. One of the earliest observations was the tedious process of program change associated with most university program revisions. Also, there was the task of development of a new course syllabus reflective of these individualized pieces of instruction and then the overwhelming undertaking of implementing delivery. There would also be the charge of assigning the course components to individual faculty members and how this would impact already cumbersome faculty load assignments. Looking farther along, another concern that needed to be addressed was that after a few semesters of this new undertaking, there would be multiple sections of this course running consecutively, creating further scheduling and personnel challenges. We also wanted to put into place a feedback loop so that we could continually monitor and measure the effectiveness of the new 'research thread.'

\section{BENEFITS}

Traditional research courses are typically constrained by a one-semester timeline which limits the learning potential that comes from student research projects. Commonly, the solution to this nearly-unmanageable schedule is to abbreviate the project development/rationale stage, to elect group research with assigned topics, or to require a project proposal versus a full research project. Adopting a year-long applied research sequence helps alleviate this difficulty and allows students time to develop an appreciation of the full research experience, from conceptualizing to presentation.

In terms of our own program improvement, we will continue to use an action research model in which we monitor and assess this applied research sequence as a solution to the problem we identified in our curriculum.

Finally, an important potential benefit, and one that we will seek to evaluate, may occur long after students leave the program. Teachers and administrators who have applied research experience, who view research as being vital to making school and district-wide decisions, are better prepared to not only generate their own research questions and gather their own data, but also to use school district data to improve student achievement.

\section{REFERENCES}

1. Berelson, B.1960. Graduate education in the united states. McGraw Hill, New York, NY.

2. Cooper, B. \& Boyd, W. (1987). The evolution of training for school administrators.

3. Darling- Hammond, L. (1996). What matters most: A competent teacher for every child. Phi Delta Kappan, 78,193-200.

4. Desforges, C. (2003). How Does Experience Affect Theoretical Knowledge for Teaching? Learning and Instruction 5, 385-400.

5. Fenning, K. (2004). Cohort Based Learning: Application to Learning Organizations and Student Academic Success. College Quarterly, Winter 7(1). Retrieved August 1, 2005 from http://www.senecac.on.ca/quarterly/2004-vol07-num01-winter/fenning.html.

6. Finney, J. E., (1992). At the crossroads: linking teacher education to school reform. ECS: Denver, CO.

7. Fullan, M. (1994). Change forces: Probing the depths of educational reform. New York: Falmer.

8. Gagne, R. (1977). The conditions of learning and theory of instruction ( $3^{\text {rd }}$ ed.). New York: Holt, Rinehart and Winston, Inc.

9. Goodlad, J. (1990). Teachers for our nation's schools. San Francisco: Jossey-Bass.

10. Grant, C. A. (1994). Best practices in teacher preparation for urban schools: Lessons from the multicultural teacher education literature. Action in Teacher Education, 14 (3), 1-18.

11. Hansen, J. (1997). Researchers in our own classrooms: What propels teacher researchers? In D. Leu, C. Kinzer, \& K. Hinchman (Eds.), Literacies for the 21st century: Research and practice (pp. 1-14). Chicago: National Reading Conference.

12. Joyce B. \& Weil M. (2000). Models of teaching (6th ed.). Boston: Allyn and Bacon.

13. Levine, A. (2005). Educating School Leaders. Washington, D.C.: The Educating Schools Project. 
14. Levine, D. U. and Lezotte, L. W. (1990). Unusually Effective Schools: A Review and analysis of Research and Practice, Madison, WI, National Centre for Effective Schools Research and Development.

15. McKay, J.A. (1992, Winter). Professional development through action research. Journal of Staff Development, 13(1), 18-21.

16. McTaggart, R. (1996). Issues for participatory action researchers in O. Zuber-Skerritt (ed.) New Directions in Action Research, London: Falmer Press.

17. Means, T., Jonassen, D., and Dwyer, F. (1997). Enhancing Relevance: Embedded ARCS Strategies vs. Purpose. Educational Technology Research and Development, 45, 5-17.

18. National Commission on Excellence in Education, A Nation at Risk: The Imperative for Educational Reform, Report to the National Secretary of Education (Washington, DC; US Department of Education; April 1983).

19. Pearson, J. (2003). Trends and Issues: Research. Clearinghouse on Educational Policy and Management, University of Oregon. Retrieved May 31, 2005 from http://cepm.uoregon.edu/trends issues/research/.

20. Powell, Authur G. University Schools of Education in the Twentieth Century, Peabody Journal of Education, v. 54, n. 1, October 1976, pp.3-20.

21. Rigden, D. W. (1996). What teachers have to say about teacher education. Perspective: Council for Basic Education, 8(1), 18.

22. U.S. Department of Education. (2003, April 3). No Child Left Behind Executive Summary. Retrieved June 1, 2005 from http://www.ed.gov/offices/OESE/esea/exec-summ.html.

23. Watts, H. (1985). When teachers are researchers, teaching improves. Journal of Staff Development, 6 (2), 118-127. 